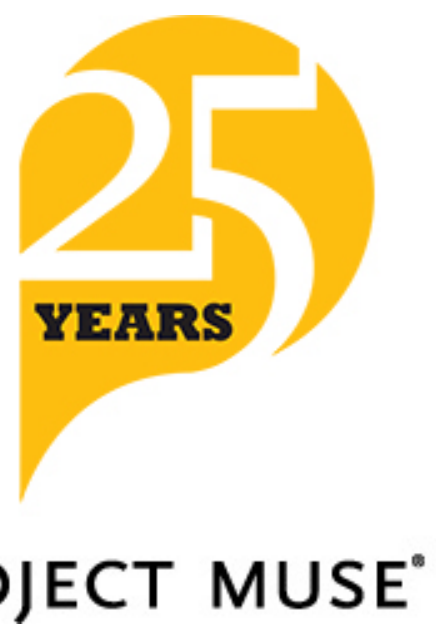

PROJECT MUSE*

Post-secular Nature and the New Nature Writing

Alexander J. B. Hampton

The

Johns

Christianity \& Literature, Volume 67, Number 3, June 2018, pp. 454-471 (Article)

Hopkins

University

Press

Published by Johns Hopkins University Press

$\Rightarrow$ For additional information about this article https://muse.jhu.edu/article/735875 


\section{Post-secular Nature and the New Nature Writing}

\author{
Alexander J. B. Hampton \\ University of Toronto, Canada
}

Christianity \& Literature 2018, Vol. 67(3) 454-471

(C) The Conference on Christianity and Literature, 2018

Reprints and permissions: sagepub.co.uk/ journalsPermissions.nav DOI: 10.1177/0148333117735878 journals.sagepub.com/home/cal

\begin{abstract}
With the turn of the twenty-first century, a group of writers began rehabilitating British nature writing and the voice of the individual interacting with it, producing what has become collectively known as the new nature writing. This examination considers how this literature represents a post-secular re-conceptualization of our relationship to nature. The new nature writing challenges a key element of the secular social imaginary, namely the subject-centered, immanence-bound, disenchanted representation of nature, which sets the self over and above nature, destabilizing existing dichotomies, and generating a multiplicity of hybridized possibilities that re-conceptualize our relationship to nature.
\end{abstract}

\title{
Keywords
}

new nature writing, nature, post-secular, Robert Macfarlane, Helen Macdonald

For a good part of the twentieth century, British nature writing found itself caught amongst the brambles. Though many authors continued to make outstanding contributions, the respect afforded to the genre was far from the heady days of Romantic and Victorian literature. ${ }^{1}$ In 1932 it came in for one of its fiercest attacks, with the highly successful and entertaining comedic novel Cold Comfort Farm by Stella Gibbons, which offered a pastiche of countryside novels by the likes of Hardy, Lawrence and Brontë. Two years later, in his novel Scoop, Evelyn Waugh offered a savage parody of the nature columnist with his character William Boot. The legacy of these popular books was to help construct a caricature of nature writers, nostalgic for a Britain that never was, which fit certain facets of the modern social imaginary. Such writers could be dismissed as reactionary Tory ruralists holding out in the back pockets of the shires, sentimental Beatrix Potter anthropomorphizers with minds cloyed by indulgent fantasy, or increasingly aged New Agers searching for an elusive holistic oneness. Conceptualized as hackneyed

\section{Corresponding author:}

Alexander J. B. Hampton, University of Toronto, Department for the Study of Religion, Jackman Humanities Building, Toronto, ON M5R 2M8, Canada.

Email: a.hamptondutoronto.ca 
and frowsty, the public voice of the individual interacting with nature quietly disappeared, to be replaced by the disembodied, objective and impassive voice of the expert; nature writing became the realm of professional biologists or conservationists. $^{2}$ Only the expertise and credentials of historians, geologists or biologists could move beyond what W. G. Hoskins described as the "sentimental and formless slush which afflicts so many books concerned only with superficial appearances." 3

With the turn of the twenty-first century, however, a group of writers began to challenge this view. Rehabilitating British nature writing and the voice of the individual interacting with it, they have begun to produce a new kind of writing about nature. Though primarily a genre of non-fiction nature prose, the movement has also manifested itself in poetry and the visual arts, though my examination here considers only non-fiction. ${ }^{4}$ This new nature writing, I will propose here, represents a postsecular re-conceptualization of our relationship to nature. It challenges a key element of the secular social imaginary, namely a subject-centered, immanence-bound, disenchanted representation of nature that sets the self over and above nature.

The shifting of the social imaginary from secular to post-secular destabilizes these dichotomies. In turn, the new nature writing plays with the possibilities opened up by this destabilization, re-conceptualizing our relationship to nature in the process. I examine this development under three key sacred-secular dichotomies: understanding the self as either open or closed to transcendent forces, conceptualizing ontological reality as either epistemologically or metaphysically located, and finally viewing nature itself as either disenchanted or enchanted. In each case, where dichotomies are broken down and confused, the new nature writing plays with new possibilities, but it does not engage in a simple return to the sacred. Instead, the post-secularity of new nature writing manifests itself through a multiplicity of hybridized prospects and opportunities.

\section{The Topography of the New Nature Writing}

In 2008 Granta: The Magazine of New Writing published an issue titled "The New Nature Writing," marking the establishment of a movement that has since grown exponentially. ${ }^{5}$ The founding edition of the occasional literary magazine Archipelago, which has acted as an organ for many of the movement's contributors, appeared in 2007. Since then, numerous contributions in the category have appeared on UK bestseller lists. In 2014 the Wainwright Prize was established in association with the National Trust to recognize this emergent genre. The same year book sales for one of the movement's leading contributors, Robert Macfarlane, surpassed 300,000 copies in the UK. Furthermore, in 2015, Helen Macdonald's $H$ is for Hawk sold more than 135,000 UK copies after it won both the Samuel Johnson and Costa Book of the Year prizes. ${ }^{6}$ The popularity and exponential growth of the new nature writing indicates that it is addressing the interest of a significant part of the reading public in the United Kingdom. In this way, the new nature writing provides a linguistic vocabulary and imaginal space where this desired alternative relationship to nature plays itself out. 
The new nature writing that has emerged over the past decade may be gathered into five regions. The first of these regions is populated by works that express a singular sensitivity and awareness of place. Some of the major works in this vein include Roger Deakin's Waterlog: A Swimmer's Journey Through Britain (1999), Kathleen Jamie's Findings (2005), and Sightlines (2012), Robert Macfarlane's Wild Places (2007), and The Old Ways: A Journey on Foot (2012), Philip Marsden's Rising Ground: A Search for the Spirit of Place (2014), and William Atkins' The Moor (2014). These and other works often describe a familiar landscape rendered afresh with the unfamiliar, or articulate a version of the wild that goes beyond a simple notion of the untouched, lushly describing an emergent fecundity, irreducible complexity, or a joyous superfluity in both native and exotic settings, which reconditions the readers' view of the landscape, and rewrites their place within nature. These topophilic writers are concerned with the way we know places, not just the places themselves, and as such their works often include the human geography of history, folklore and etymology, interwoven with natural history.

There is also a province of topophilic literature rooted more firmly to a single place. The model for these writers is the urtext of the English genre, Gilbert White's Natural History and Antiquities of Selborne (1789). This subset includes such texts as Stephen Moss's Wild Hares and Hummingbirds: The Natural History of an English Village (2010), John Stempel-Lewis' Meadowland: The Private Life of an English Field (2014), and The Running Hare (2016), Mark Cocker's Claxton: Field Notes from a Small Planet (2014), and Rob Cowen's Common Ground (2015). Fitting more peripherally into this territory is the work of Tim Robinson, for example his Connemara trilogy, Connemara: Listening to the Wind (2006), Connemara: The Last Pool of Darkness (2008), and Connemara: A Little Gaelic Kingdom (2011). In these works, pace is dictated by a single place; they depict an intimate relationship between the writer and the location, and cultivate a deep connection for the reader. These descriptions, sometimes of a single field over a single year, do not intend to be parochial, but rather to demonstrate the exponential and overwhelming complexity and depth of a single place; conversely, they offer a deep sense of humanity's embeddedness in nature.

A third major region of the new nature writing is similarly concerned with the re-integration of the self into nature, but its active ingredient is not the disposition to embark on an excursion, but the imposition of personal crisis: loss, depression, addiction, or childhood trauma. Contributions in this vein include Richard Mabey's Nature Cure (2005), Helen Macdonald's H is for Hawk (2014), Amy Liptrot's The Outrun (2015), Katherine Norbury's The Fish Ladder: A Journey Upstream (2015), and Michael McCarthy's Moth Snowstorm: Nature and Joy (2015). In these works, the natural world provides a way for individual authors to deal with the experience of crisis, not as the place for the projection of one's emotions, but as the space whereby perspective is gained, and new meaning, in the context of nature, is discovered. The shock of death is overcome as one re-attunes to the cycle of life. The alienation of depression is overcome through a restored sense of participation. The rich fecundity of nature overcomes the poverty 
of urban indifference. In each of these instances, a sense of being and place restores the self.

Yet another variety of nature writing's regions tells its story by focusing on a particular animal species. Examples within this strain include Mark Cocker's Crow Country: A Meditation on Birds, Landscape and Nature (2008), Tim Dee's The Running Sky: A Bird-Watching Life (2009), Miriam Darlington's Otter Country (2012), Patrick Barkham's Badgerlands (2013), and Dave Goulson's A Sting in the Tail (2013). These texts, through the personal journey or experience of the author, introduce readers to curious, fascinating and unknown aspects of everyday wildlife. In demonstrating the exotic nature of the ordinary, they make an argument, implicit or explicit, for a renewed relationship with nature. Through personal stories, whether of the authors themselves or with conservationists or others with a special relationship to the selected animal, these works illustrate how certain species impact human lives in complex and seemingly mysterious ways.

Finally, and more recently, some authors have taken a more circumspect approach to new nature writing. Both Nina Lyon's Uprooted: On the Trail of the Green Man (2016), and Will Ashon's Strange Labyrinth: Outlaws, Poets, Mystics, Murderers and a Coward in London's Great Forest (2017), add to the literature less by offering a direct critique than by intimating a refreshingly wry and somewhat sceptical view of some of the proposed routes that are to lead us back into nature.

\section{What Makes New Nature Writing 'New': A Post-secular Framework}

The name "new nature writing" is not unproblematic. Many of the authors included under the banner have expressed some dissatisfaction with the designation, and with the notion that it constitutes a movement, despite the fact that a number of the principal authors are friends, sometime collaborators, and even neighbors. To describe it as a genre is also problematic, as its forms are many. Amongst the abstract divisions of creative non-fiction, one can find contributions to the body of the new nature writing classified under natural history, travel writing, and memoir.

Despite these problems, however, the newness of new nature writing can be understood by distinguishing it from Romantic and natural history nature writing. On one hand, it is more hesitant to consider nature in a metaphysical context than is the tradition that develops out of Romanticism. On the other hand, the author takes on a more central role in the new nature writing than writing in the natural history tradition. Nonetheless, the new nature writing carries forward aspects of both of these traditions: from the Romantic, it expresses an unease with the construction of the rationalized relationship of the individual and nature, and from natural history writing, it registers the importance of accurate description.

Two passages help in elucidating these complicated characteristics. The first is taken from Nina Lyon's Uprooted, which challenges objectifying human 
points of view and their construction of nature, whether seemingly theological or rational:

What was needed was a renunciation of the Enlightenment idea of humans being special. And so, strangely, the image of the Green Man had nearly come full circle. We needed him again, for some reasons that were, in a way, the same, and for some that were radically different $[\ldots]$ he was now a reminder that we needed to get out of the man-shaped Church and post-Church head-space, with its man-God and the men made in His image, and all the stupid things they did and do, all giddy with power to abuse. We needed to get over ourselves and find ourselves again, our smaller selves, entwined with the selves of all other things. ${ }^{7}$

Lyon's consideration of the role of the Green Man is critical of both an Enlightenment-secularist narrative, too willing to dismiss religion as ill-founded superstition, and equally critical of the institutional church, which would abuse its privilege by placing institutional needs above all. Both the "man-shaped Church" and "post-Church head-space" are reflective for Lyon of a shared point of view, which privileges the human perspective, understood here as an all-seeing abstract eye. We find a similar critique in Richard Mabey's Nature Cure, which challenges the convention of the excised author in natural history writing:

It's become customary, on this side of the Atlantic, stiffly to exclude all such personal narratives from writings about the natural world, as if the experience of nature were something separate from real life, a diversion, a hobby; or perhaps only to be evaluated through the dispassionate and separating prism of science. It has never felt like that to me [...] it's seemed absurd that, with our new understanding of the kindredness of life, so-called 'nature writing' should divorce itself from other kinds of literature, and from the rest of human existence. ${ }^{8}$

Both passages express a critical awareness of a structural narrative that casts the view of the individual in an objective, dominating position in relation to nature. As Mabey observes, this objectifying eye also devaluates the subjective experience of the individual.

The new nature writers, by contrast, wish to describe a relationship to nature that is not a monological imposition that pretends that the eye of the beholder offers an objective rendering of the observed natural world. Instead, they seek to develop, through a re-assertion of the voice of the individual in nature, a subjective dialogue with the natural world. In the context of landscape writing, Robert Macfarlane expresses how this dialogue can be achieved: "language is used not only to navigate but also to charm the land. Words act as compass; place-speech serves literally to en-chant the land - to sing it back into being, and to sing one's being back into it." Alternatively, this is the space that Tim Robinson describes in Connemara: Listening to the Wind as "the boundary region between established truth and unstable imaginings that is my preferred territory." 10 In these, and 
many other instances, the liminal language of imagination and enchantment is always close to the surface as the new nature writer seeks to re-conceptualize nature.

To more fully grasp the connection between this re-evaluation of the framework through which nature is conceptualized and the larger discourse of the post-secular, we can turn to what Charles Taylor has called the social imaginary. Taylor defines the "social imaginary" as a framework that allows a community to "imagine their social existence, how they fit together with others, how things go on between them and their fellows, the expectations which are normally met, and the deeper normative notions and images which underlie these expectations." 11 The rethinking of the nature / human dichotomy highlighted by the new nature literature takes place during the subsidence of one social imaginary, the secular, and the seeming emergence of a new, post-secular one. The emergence of the post-secular has been the topic of consideration for a diverse range of thinkers at the turn of the twenty-first century. The work of Peter Berger, William Connolly, Jacques Derrida, Jürgen Habermas, Pierre Hadot, John Milbank, Richard Rorty, Charles Taylor and Gianni Vattimo, among many others, indicates a growing awareness of the role of secularization as a structural narrative, responsible for determining a set of assumptions in relation to the self, nature and the divine. In the sacred social imaginary the answers to fundamental questions concerning meaning, value, and the truth had their ultimate source in the supernatural order. Alternatively, in the secular social imaginary these answers are located wholly within the natural order, understood as operating independently from the supernatural. ${ }^{12}$ The apparent breakdown of an overarching secular narrative brings this solidified dichotomy once more into play. In a post-secular space the sacred once again becomes available, albeit tentatively.

The often spiritually-inflected language of the new nature writing can be given theoretical contextualization through the critical observations of Bruno Latour on the nature of modernity. In We Have Never Been Modern (1991), Latour argues that the seemingly purified forms of human culture and non-human nature are supported by a hidden, complex network of hybridization, which may be understood better in terms of the children's game "Mother, may I?" than it can be in terms of actual reality. ${ }^{13}$ Latour explains that the purity of modernity is maintained so long as we are considering it, but once we look away a complex commerce of hybridization occurs behind our backs between human culture and nonhuman nature. The moment we look back, everything once again freezes into purified domains: "Everything happens in the middle, everything passes between the two, everything happens by way of mediation, translation and networks, but this space does not exist, it has no place. It is the unthinkable, the unconscious of the moderns." "14 Latour's characterization of modernity is far more complex than his analogy of the children's game, though here it helps us to grasp what we observe in new nature writing, which offers us a description of the moment when the participants of the game are caught moving, carrying out their clandestine commerce in the unacknowledged middle. 
This is similar to John McClure's description of post-secular fiction as "a mode of being and seeing that is at once critical of secular constructions of reality and of dogmatic religiosity." 15 The post-secular is set apart from traditional religion because it does not provide, or even aspire to offer, a fully articulated vision of a re-enchanted cosmos. Equally, it is nothing like a fundamentalist or New Age program, which aims to single out a particular historical present as a rejoicing moment of religious return. ${ }^{16}$ Instead, what post-secular literature reflects is an ontological indeterminacy, a disruption of the way the secular social imaginary constructs reality, and its replacement with hybridized idioms that are partial and open. McClure's characterization of post-secular fiction can equally be applied to the creative non-fiction of the new nature writing. What we glimpse in the postsecular space of new nature writing is the confused hybrid middle that, according to Latour, has always existed beneath the modern secular imaginary.

\section{Symptoms of Post-secularism}

The shift from a secular to a post-secular social imaginary destabilizes previously resolved sacred-secular dichotomies. The new nature writing plays with the possibilities opened up by this destabilization. The result, however, is by no means a wholesale return to a sacred framework. Instead, both sacred and secular options remain in play, resulting in the partial and open hybridized idioms described by McClure. This process can be observed within the context of three such dichotomies, each of which has been the object of critical consideration by recent scholarship that takes up, either directly or indirectly, the question of post-secularity. The first of these dichotomies considers the self, and whether it is open or closed to the influence of supernatural forces. The second considers the nature of reality and its conceptualization as either epistemological or ontological. Finally, the third considers nature as either disenchanted, and capable of being understood within wholly immanent human terms, or enchanted, and thereby consistently manifesting reality beyond exhaustive rational human conceptualization. The unsettling of these dichotomies is characteristic of post-secularity; moreover, the hybrid reasoning that it engenders may be considered a symptom of the kind of post-secularism found throughout the new nature writing.

\section{Self}

In A Secular Age (2007) Charles Taylor describes a change in the concept of the self, its place in nature, and its relation to the supernatural. The premodern self, Taylor proposes, was thought of as open to supernatural forces and in general to powers beyond itself; it was "porous." The modern self, by contrast is "buffered" against those things; thoughts and feelings belong to minds and selves conceived as independent and autonomous. ${ }^{17}$ Though Taylor prefers to see this change as a complication of the secular rather than an example of the post-secular, for the purposes of this examination it is his description of the constitution of the self 
that is key. He describes how the antique and mediaeval porous self occupied a theurgic cosmos, wherein transcendent forces shaped all finite reality, both the self and nature. ${ }^{18}$ Whether these forces were understood as divine universals, or as angels or demons, individuals could interact and influence them through sacraments, magic or prayer. Taylor outlines how this transcendent worldview changed through the exercise of discipline and reform, which gradually tamed uncontrolled and supernatural forces. Coalescing in the Reformation, and affected through a growing middle class, this process of discipline corralled disruptive beliefs and isolated the now buffered self from nature, with the aim of securing a well-ordered and industrious society. ${ }^{19}$ The fundamental change from the porous to the buffered self is one of epistemic dynamics: before, both nature and the self are held together by the transcendent forces that shape them; afterwards, nature and the self are separated from one another, and shaped by forces immanent to a now de-mystified cosmos.

The works of new nature writing are populated by moments that seek to tear down the buffers that Taylor describes, that rebel against the discipline that established them, re-wilding the self and re-integrating it into nature. Michael McCarthy in The Moth Snowstorm argues that "passionate feelings of belonging, of yearning, and of love" for nature are definitive for the human species, but that we have come to be alienated from them:

On the surface, in our everyday lives, this bond is largely invisible, it is very generally unfelt, as it has not only been overlain by the five hundred generations of culture which followed the conquering of nature by the farmers, but for those of us... who live in towns and cities in an increasingly hyperactive age, it is buried under an impenetrable mass of urban mental clutter. Yet deep down, it is there: we may have left the natural world, but the natural world has not left us. ${ }^{20}$

Here, McCarthy expresses a desire central to much of the new nature writing, which seeks to return readers to a sense of interconnectedness, or what John Lewis-Stempel describes in Meadowland as "a way of thinking about nature which is not Us and Them, but We together."21

Roger Deakin's Waterlog picks up on this strain. In one representative passage, he describes his desire to swim the Corryvreckan whirlpool that forms in the narrow strait between Jura and Scarba of Western Scotland:

I longed for the heightened experience of somehow physically sharing in the Corryvreckan's excess of mad energy. Perhaps this is what a wolf feels when it bays at the moon, and perhaps it was quite as impractical a desire. Nevertheless, I felt that the whirlpool, in league with the moon, and renewing itself at every tide, could likewise renew the swimmer bold enough to seize the moment and cross it in a moment of repose. It would be like tiptoeing past a sleeping tiger. Keats wrote in a letter to his friend Bailey, 'If a sparrow come before my window, I take part in its existence and pick about in the gravel.' By swimming the Corryvreckan, I wanted to 'take part in its existence', to feel part of it, to swim with it, not against it, in one of its gentler moods. ${ }^{22}$ 
Deakin's re-integration is literally a re-immersion into the watery places that modern Britons increasingly find themselves alienated from. It describes, on the part of the author, a visceral need to return to an elemental part of himself. $\mathrm{He}$ rebels consciously against discipline, noting his own impracticality, and his desire to physically share in the same "mad energy" which generates the whirlpool, and brings the wolf to bay at the moon. Deakin's reference to Keats carries his own intimations much further. The same letter contains Keats' famous musings on "the holiness of the Heart's affections and the truth of the Imagination." ${ }^{23}$ This connects Deakin's thoughts, at the very least by association, to the Romantic desire to restore, through art and nature, the participatory ontology of the porous self. The whirlpool, like the sparrow, offers a moment of participatory porousness, where an unbuffered self takes part in a natural existence that is greater than the self.

There is nothing in these descriptions - the whirlpool, the sparrow, the mad energy of nature - that is transcendent. In instances such as these, the uncontrollable supernatural forces that characterized the premodern social imaginary are not present. Nevertheless, there is an opening up of the buffered self, and a desire to overcome its alienation from forces within nature, both understood and mysterious. The result is a kind of hybrid, a turn away from the secular social imaginary that is not a return to the sacred social imaginary.

\section{Ontology}

A more complex metaphysical question emerges out of this re-opened self. The work of Wouter Goris, Jean-François Courtine, Ludger Honnefelder, and above all Jan Aertsen has illuminated a shift from a transcendent and metaphysical worldview to an immanent epistemological one. This scholarship has not been directly concerned with the question of secularization and post-secularity, but rather with a key intellectual moment in the transition from a sacred to a secular social imaginary. For someone in the sacred social imaginary like Aquinas, transcendentals such as one (ипит), true (verum), good (bonum), and above all being (ens), were real divine names, participating in creation, structuring and sustaining it, and in so doing revealing the sustaining metaphysical divinity beyond the physical. For example, Aquinas' understanding of the transcendentals allowed him to see creation itself as revelatory: "because we come to a knowledge of God from other things," he wrote, "the reality in the names said of God and other things belong by priority in God according to His mode of being, but the meaning of the name belongs to God by posteriority. And so He is said to be named from His effects." 24

Transcendentals also structured the experience of reality for Kant, but they were redefined in the context of idealism, such that they are not real in the sense that they exist beyond the mind. Rather, they were a priori, and consequently "nothing but logical requirements and criteria of all knowledge of things in general, and lay out for such knowledge the categories of quantity, namely, unity, plurality, and totality." 25 
Kant made this claim with the expressed aim of countering the "transcendental philosophy of the ancients." ${ }^{26}$ Under the metaphysical definition of the transcendentals, the divinity is responsible for the metaphysical structure of reality that undergirds both nature and the self. Within a modern epistemological definition, by contrast, it is the mind of the individual that is responsible for structuring reality.

For new nature writing, both of these possible constructions of the transcendental are in play, manifesting themselves in hybridized form. One example may be found in Marsden's Rising Ground, a book about the West Country. Marsden makes a distinction, familiar from cultural geography and anthropology, between space and place. Whereas place is distinctive, a possessed of inherent qualities that necessitate a dialogical relationship between the subject and the object, space, writes Marsden, is "an idealized location, abstracted from the real world, a template which can be dropped over any point on the earth's surface." ${ }^{27}$ Here both a metaphysical and an epistemological possibility of understanding location are possible. Marsden's concern with the recovery of the spirit of place is expressed in his consideration of Glastonbury, and the many narratives that emerge out of the place:

For centuries Glastonbury stood as a ruin, visited only by a few curious antiquaries. But during the last century or so, its appeal has been growing - no longer as a place of Christian pilgrimage, nor as a site with the Arthurian emphasis of Tintagel, but as a combination of these and more, a post-modern stew of myths and traditions. Maybe it really is the energy lines, those hidden channels of power that converge at this place to give it its aura and generate its miracles. Or maybe it's simply the shape of the hill. ${ }^{28}$

Here the source of Glastonbury's attraction, historical and present-day, may be either the metaphysical or the physical. In this example, as elsewhere in the movement's literature, the post-secular view of nature leads to a kind of narrative abundance, tempered with what one might call a metaphysical reticence. The possibility of metaphysics is re-opened, but it is not returned to its previous status as queen of the sciences.

The reasoning behind this becomes clear in an example from Nina Lyon's Uprooted, which specifically addresses the question of metaphysics. Lyon employs the symbol of the Green Man to explore nature's superior power and human alienation from it. She writes:

The revival of the Green Man... was entirely metaphysical in the grand Romantic sense as well as the philosophical sense, of there being more going on with it than might appear at first glance. If you wanted to call this God, fair enough, but if you wanted to avoid all that you could call it something else instead. You could say that Nature had a soul, or a will, or consciousness. There were options. ${ }^{29}$

Traditional metaphysics places divinity above humanity, and humanity, by virtue of intellect, above the rest of nature. When the transcendentals were in effect transferred from the mind of God to the mind of the human, the hierarchy 
remained, but without its divine component. Key to new nature writing is a rejection of this hierarchical, subject-centred epistemology, which it understands to be the source of modern alienation from nature, the underlying justification for its exploitation, and the root cause of its degradation. Lyon challenges this fundamental component of the secular social imaginary: "For as long as you believe that humans are special, you cast all activity relating to life at large as an act of largesse on the part of humankind." 30 The rejection of an approach in which the human is the determiner of objective truth, however, does not allow any simple return to the metaphysical hierarchy of the sacred social imaginary in which the physical world is constituted by the metaphysical one. As seen here in both Marsden and Lyon, the possibility of narrative abundance, and the rejection of anthropocentrism, discourages the privileging of any one position and with this the establishment of hierarchies. Traditional metaphysics, too, de-centers the self, but this is not the direction taken by the new nature writing. Rather, the possibility of metaphysics is re-opened but not given priority over the physical. ${ }^{31}$

\section{Nature}

Finally, the third dichotomy considers how nature is conceptualized. It may be understood as either disenchanted, and therefore capable of being comprehended within wholly immanent human terms, or enchanted, and thereby manifesting a reality beyond exhaustive rational human conceptualization. This process of disenchantment is key to the notion of secularization, and central to the thought of Max Weber, Max Horkheimer, Theodor Adorno, John Bossy, Jane Bennett, Charles Taylor, and many others. The enchanted world of the sacred social imaginary was a participatory universe in which all things, and particularly nature, were animate, connected, and potential in ways that could only partially be understood, and only partially controlled. ${ }^{32}$ By contrast, in the disenchanted world, according to Max Weber's familiar argument, "we are not ruled by mysterious or unpredictable forces, but... on the contrary, we can in principle control everything by means of calculation. ${ }^{, 33}$ Disenchantment does not imply a particular understanding of nature so much as a determinative conviction that if one wished to understand the operation of any particular aspect of nature, one could do so with increasing exactitude. This conviction is expressed in naturalism, whose unrestricted form maintains that all reality falls within the scope of scientific enquiry, and that its accounts are to be defined over and against any form of supernaturalism. ${ }^{34}$

As in the previous two cases, the irresolution of settled dichotomies leads the new nature writing to play in the space between the enchanted and disenchanted, forming hybrid positions that redefine the relationship of the individual to nature. Informed by both their semi-porous self and a reticently metaphysical outlook, the new nature writers resist any disenchanted narrative that would claim to be capable of fully understanding and controlling nature. Instead, they encounter nature anew. This re-encounter takes many forms, but two manifestations in particular stand out. The first is the irreducibility of nature, whereby the natural world 
possesses qualities that resist description and articulation. The second, the transverse form of this resistance, is descriptive proliferation, a kind of lush prose or thick description, oftentimes evoked by these moments of resistance. Both express the same uncircumscribable quality of their natural objects, manifesting the restlessness of the new nature writing at the boundaries of the secular social imaginary.

In the case of nature's irreducibility, the limitations of a disenchanted secular social imaginary are challenged by the movement's demonstration of the inadequacy of present categories to adequately represent nature and our experience of it. It is here, in the moment when nature resists language, presenting itself as irreducible to disenchantment, that a space clears for a re-engagement with nature. The encounter with the irreducible records the moment when the writer, and by extension the reader, engage in a process of deferred evaluation, which in turn opens up a dialogue with the object of resistance. In this dialogue, subject-centered, disenchanted concepts are no longer imposed upon the object; rather the object comes to speak itself. To encounter nature as irreducible is to come across something which makes a strong claim, which resists any reduction to existing human categories and narratives, and which causes words to respond to, rather than impose, meaning. One such moment is articulated in Tim Robinson's Connemara: Listening to the Wind:

Once when I was lying on the terrace of our house overlooking the bay, listening to music from the room behind me and watching a summer night subvert the scale of all things, I felt I could raise my hands and spread my fingers over the mountain range, solidly dark against the still wine-flushed sky, as if over the keyboard of a piano, and produce one tremendous, definitive Connemara chord. But Connemara tends to undefine itself from minute to minute, and this Beethoven moment quickly passed. The range of peak became sheet iron, two-dimensional, a serrated rim to the floor of the world, dangerous to the imagined touch. ${ }^{35}$

In this passage, the landscape first presents itself as a musical cipher, capable of the author's tactile decoding, only to metamorphose, and present a resistance so stark that it is even dangerous to the touch, indicating a latent, wild, and untamed character. Robert Macfarlane, whose most recent book focuses upon the vast vocabulary that descriptive proliferation generates, also makes allowances for such moments of resistance: "There are experiences of landscape that will always resist articulation, and of which words offer only a remote echo - or to which silence is by far the best response. Nature does not name itself. Granite does not self-identify as igneous. Light has no grammar. Language is always late for its subject." $" 36$

This resistance is equally displayed in Helen Macdonald's visceral $H$ is for Hawk. The book describes a year the author spent training a goshawk following the death of her father, and centers upon a creature of remarkable resistance and irreducibility. However, in the following example, which occurs 
during her first encounter with the hawk, as the breeder opens the box in which it has been transported, we also encounter a moment of descriptive proliferation:

Concentration. Infinite caution. Daylight irrigating the box. Scratching talons, another thump. And another. Thump. The air turned syrupy, slow, flecked with dust. The last few seconds before a battle. And with the last bow pulled free, he reached inside, and amidst a whirring, chaotic clatter of wings and feet and talons and a high-pitched twittering and it's all happening at once, the man pulls an enormous, enormous hawk out of the box and in a strange coincidence of world and deed a great flood of sunlight drenches us and everything is brilliance and fury. The hawk's wings, barred and beating, the sharp fingers of her dark-tipped primaries cutting the air, her feathers raised like the scattered quills of a fretful porpentine. Two enormous eyes. My heart jumps sideways. She is a conjuring trick. A reptile. A fallen angel. A griffon from the pages of an illuminated bestiary. Something bright and distant, like gold falling through water. ${ }^{37}$

In examples such as these, we encounter what Robert Macfarlane has aptly described as "writing so fierce in its focus that it can change the vision of its readers." ${ }^{38}$ Here the hawk is represented as an experience that we cannot subsume into a system or narrative. Even syntax struggles to keep up with the demands of the author's encounter. As Macdonald writes elsewhere of the hawk, "She is real. She can resist the meanings humans give to her." ${ }^{39}$ The density and detail of the description corresponds to a distinction made by Macfarlane between precision and rigor: "the former being exhilaratingly exact, and the latter being grimly exacting." 40 The grimness of the latter offers an exhaustive dissection of its object, aiming to close off any further description beyond its own. Alternately, the proliferation that characterizes the former arises from the irreducibility of the encounter with nature.

In these and other moments, the new nature writing presents nature "as such," containing neither components nor commodities we can measure and master, but incomprehensible forces both within it and within ourselves-in-nature, with which we must negotiate. In encountering the Connemara landscape or the Goshawk we are not called back to a previous enchanted narrative, nor presented with anything that corresponds to a disenchanted one. Instead, as readers, we encounter something irreducible, which cannot be exhausted by a disenchanted, subject-centered immanent narrative.

\section{Nature as the Stage for Post-secularity}

If we understand the secular social imaginary as holding a largely naturalist view of nature, then the new nature writing sets out an alternative vision of nature and our relationship to it. In its pages we observe the destabilization of the secular, subjectcentered, immanence-bound, and disenchanted understanding of nature, and the 
re-emergence of dialogical, transcendent, and enchanted possibilities. As a burgeoning feature of the contemporary British literary scene, the desire of the new nature writers to go beyond the limits of naturalism evinces the shifting ground of the present-day social imaginary. In doing so this writing responds to a strong public disquiet with key features of the secular social imaginary, and in this regard we may consider it as offering a post-secular understanding of nature and our relationship with it.

The new nature writing, however, does not demonstrate any substantive return to the transcendent nature of a sacred social imaginary. In offering a form of re-enchantment, it undertakes no simple return to enchantment, and certainly no simple return to religion. Instead, it resists, often implicitly, the traditional language of theology, still tainted as retrograde by the secularization thesis. The genre's language is popular, not constructive, and spiritual, as opposed to overtly religious. Playing with the possibilities opened up by the destabilization of the secular social imaginary in order to re-conceptualize our relationship to nature, the new nature writing offers a multiplicity of hybridized possibilities. We see this in its presentation of a nature that resists reduction to the narratives of naturalism, and in turn re-integrates the self into nature, often through the first step of legitimizing the force of our imaginative responses to it. As such, the new nature writing is best understood as charting something emergent, and it is impossible at this stage to put enough distance between its beginning and the present to make any decisive characterization comfortable. What can be said with some degree of confidence, however, is that this genre reflects an increasingly apparent and fundamental change in our epistemic conditions, wherein the whole context of our experience and understanding takes place, and that nature is a stage well suited to observing this transformation.

\section{Notes}

1. This paper has benefited from the comments of the editor, as well as conversations with Richard Mabey, Robert Macfarlane, Philip Marsden, Nina Lyon, and the students of my class on the new nature writing at Barrett Honors College.

2. Richard Mabey, "Introduction," in Second Nature, ed. Richard Mabey (London: Cape, 1984), ix-xix.

3. W. G. Hoskins, The Making of the English Landscape (London: Hodder and Stoughton, 1955), 13.

4. I consider the poetry of the new nature writing in a forthcoming paper. For poetic examples see Harriet Tarlo, ed. The Ground Aslant: An Anthology of Radical Landscape Poetry (Exeter: Shearsman, 2011). For examples in art see Laurence Edwards, Laurence Edwards (London: Mussum's, 2016), and Richard James, Assemblages (Uppingham: Goldmark, 2016).

5. Jason Cowley, "Editors' Letter: The New Nature Writing," Granta, 102 (2008), 7-12. Claire Armitstead, "Happiness to Mindfulness, via Wellbeing: How Publishing Trends Grow." The Guardian, 14 March 2016, accessed 12 January 2017, https://www.theguardian.com/books/booksblog/2016/mar/14/happiness-to-mindfulness-via-wellbeing-howpublishing-trends-grow 
6. Doward, Jamie. "Hawks, Butterflies, Coasts and Footpaths: How Nature Writing Turned to Literary Gold," The Observer, 22 March 2015, accessed 12 January 2017, https://www.theguardian.com/books/2015/mar/22/nature-writing-literary-gold

7. Nina Lyon, Uprooted: On the Trail of the Green Man (London: Faber and Faber, 2016), 48-9.

8. Richard Mabey, Nature Cure (London: Vintage, 2015), 22-3.

9. Robert Macfarlane, Landmarks (London: Hamish Hamilton, 2015), 22.

10. Tim Robinson, Connemara: Listening to the Wind (Dublin: Penguin Ireland, 2006), 374.

11. Charles Taylor, Modern Social Imaginaries (Durham: Duke University Press, 2004), 23.

12. Charles Taylor, A Secular Age (Cambridge, MA: Belknap, 2007), 542.

13. Bruno Latour, We Have Never Been Modern (Cambridge, MA: Harvard University Press, 2002), 11, 37.

14. Latour, We Have Never Been Modern, 37.

15. John A. McClure, Partial Faiths: Postsecular Fiction in the Age of Pynchon and Morrison (Athens: University of Georgia Press, 2007), ix.

16. McClure, Partial Faiths, 3, 6.

17. Taylor, A Secular Age, 37-42, 262-64, 300-7.

18. Charles Taylor, "Buffered and Porous Selves," The Immanent Frame, 2 September 2008, accessed 12 January 2017, http://blogs.ssrc.org/tif/2008/09/02/buffered-and-porousselves/, A Secular Age.

19. Taylor, A Secular Age, 105-6

20. Michael McCarthy, Moth Snowstorm: Nature and Joy (London: John Murray, 2015), 612.

21. John Stempel-Lewis, Meadowland: The Private Life of an English Field (London: Black Swan, 2015), 283.

22. Roger Deakin, Waterlog: A Swimmer's Journey Through Britain (London: Chatto \& Windus, 1999), 250.

23. John Keats, Selected Letters, edited by Robert Gittings (Oxford: Oxford University Press, 2002), 36.

24. Thomas Aquinas, Summa Theologiae, edited by Thomas Gilby (London: Blackfriars, 1964-76), I, c. 34 [6].

25. Immanuel Kant, Kant's Gesammelte Schriften. Edited by Royal Prussian (subsequently German, then Berlin-Brandenburg) Academy of Sciences (Berlin: Reimer, 1902-), III, B114.

26. Kant, Gesammelte Schriften, III, B113.

27. Philip Marsden, Rising Ground: A Search for the Spirit of Place (London: Granta, 2014), 23.

28. Marsden, Rising Ground, 110.

29. Lyon, Uprooted, 268.

30. Lyon, Uprooted, 48.

31. There is a direct objection to the metaphysical tradition in the writing of Richard Maybe. See Second Nature, xii, and 'The Real Stuff' in Selected Writings 1974-1999 (London: Chatto \& Windus, 1999), 119-27.

32. Stephen Wilson, The Magical Universe (London: Hambledon, 2000), xvii-xviii.

33. Max Weber, The Vocation Lectures, translated by Rodney Livingstone (Indianapolis: Hackett, 2004), 13.

34. Jeffery Stout, "Naturalism," in Encyclopedia of Religion, 2nd ed., edited by Lindsay Jones, Mircea Eliade and Charles J. Adams (Detroit: Macmillan Reference, 2005), 6429-30.

35. Robinson, Connemara, 362.

36. Macfarlane, Landmarks, 10.

37. Macdonald, Helen. H is for Hawk. London: Vintage, 2014, 53. 
38. Macfarlane, Landmarks, 1.

39. Macdonald, $H$ is for Hawk, 181.

40. Macfarlane, Landmarks, 101.

\section{Works Cited}

Aertsen, Jan, Medieval Philosophy as Transcendental Thought: From Philip the Chancellor (ca. 1225) to Francisco Suárez. Leiden: Brill, 2012.

Aquinas, Thomas. Summa Theologiae. Edited by Thomas Gilby, London: Blackfriars, 1964-76.

Armitstead, Claire. "Happiness to Mindfulness, via Wellbeing: How Publishing Trends Grow." The Guardian, 14 March 2016. https://www.theguardian.com/books/booksblog/2016/mar/14/happiness-to-mindfulness-via-wellbeing-how-publishing-trends-grow (accessed 12 January 2017).

Ashon, Will. Strange Labyrinth: Outlaws, Poets, Mystics, Murderers and a Coward in London's Great Forest. London: Granta, 2017.

Atkins, William. The Moor. London: Faber \& Faber, 2014.

Barkham, Patrick. Badgerlands: The Twilight World of Britain's Most Enigmatic Animal. London: Granta, 2014.

Berger, Peter L. The Desecularization of the World: Resurgent Religion and World Politics. Grand Rapids: Eerdmans, 1999.

Cocker, Mark. Crow Country: A Meditation on Birds, Landscape and Nature. London: Jonathan Cape, 2007.

Cocker, Mark. Claxton: Field Notes from a Small Planet. London: Jonathan Cape, 2014.

Connolly, William E. Why I Am Not a Secularist. Minneapolis: University of Minnesota Press, 1999.

Courtine, Jean-François. Suarez et le système de la métaphysique. Paris: Presses Universitaires de France, 1990.

Cowen, Rob. Common Ground. London: Hutchinson, 2015.

Cowley, Jason. "Editors' Letter: The New Nature Writing." Granta, 102 (2008), 7-12.

Darlington, Miriam. Otter Country: In Search of the Wild Otter. London: Granta, 2012.

Deakin, Roger. Waterlog: A Swimmer's Journey Through Britain. London: Chatto \& Windus, 1999.

Dee, Tim. The Running Sky: A Bird-Watching Life. London: Jonathan Cape, 2009.

Derrida, Jacques. The Gift of Death. Translated by David Wills. Chicago: University of Chicago Press, 1995.

Doward, Jamie. "Hawks, Butterflies, Coasts and Footpaths: How Nature Writing Turned to Literary Gold." The Observer, 22 March 2015. https://www.theguardian.com/books/ 2015/mar/22/nature-writing-literary-gold (accessed 12 January 2017).

Edwards, Laurence. Laurence Edwards. London: Mussum's, 2016.

Gibbons, Stella. Cold Comfort Farm. London: Allen Lane, 1976.

Goris, Wouter. Absolute Beginners: Der mittelalterliche Beitrag zu einem Ausgang vom Unbedingten. Leiden: Brill, 2007.

Goulson, Dave. A Sting in the Tail. London: Jonathan Cape, 2013.

Habermas, Jürgen. Nachmetaphysisches Denken. Frankfurt: Suhrkamp, 1989.

Habermas, Jürgen. "Die Dialektik der Säkularisierung”, Blätter für deutsche und internationale Politik, 4 (2008), 33-46.

Hadot, Pierre. Qu'est-ce que la philosophie antique? Paris: Gallimard, 1995. 
Honnefelder, Ludger. Scientia Transcendens: Die Formale Bestimmung der Seiendheit et Realität in der Metaphysik der Mittelalters und der Neuzeit. Hamburg: Meiner, 1990.

Hoskins, W. G. The Making of the English Landscape. London: Hodder and Stoughton, 1955.

The Immanent Frame, The. http://blogs.ssrc.org.

James, Richard. Assemblages. Uppingham: Goldmark, 2016.

Jamie, Kathleen. Findings. London: Sort Of Books, 2005.

Jamie, Kathleen. Sightlines. London: Sort Of Books, 2012.

Kant, Immanuel. Kant's Gesammelte Schriften. Edited by Royal Prussian (subsequently German, then Berlin-Brandenburg) Academy of Sciences, Berlin: Reimer, 1902-.

Keats, John. Selected Letters. Edited by Robert Gittings. Oxford: Oxford University Press, 2002.

Latour, Bruno. We Have Never Been Modern. Cambridge, MA: Harvard University Press, 2002.

Liptrot, Amy. The Outrun. Edinburgh: Canongate, 2015.

Lyon, Nina. Uprooted: On the Trail of the Green Man. London: Faber and Faber, 2016.

Mabey, Richard, ed. Second Nature. London: Cape, 1984.

Mabey, Richard. Selected Writings 1974-1999. London: Chatto \& Windus, 1999.

Mabey, Richard. Nature Cure. London: Vintage, 2015.

Macdonald, Helen. $H$ is for Hawk. London: Vintage, 2014.

Macfarlane, Robert. Wild Places. London: Granta, 2007.

Macfarlane, Robert. The Old Ways: A Journey on Foot. London: Hamish Hamilton, 2012.

Macfarlane, Robert. Landmarks. London: Hamish Hamilton, 2015.

Marsden, Philip. Rising Ground: A Search for the Spirit of Place. London: Granta, 2014.

McCarthy, Michael. Moth Snowstorm: Nature and Joy. London: John Murray, 2015.

McClure, John A. Partial Faiths: Postsecular Fiction in the Age of Pynchon and Morrison. Athens: University of Georgia Press, 2007.

Milbank, John. Theology and Social Theory: Beyond Secular Reason. Oxford: Basil Blackwell, 1990.

Moss, Stephen. Wild Hares and Hummingbirds: The Natural History of an English Village. London: Vintage, 2012.

Norbury, Katherine. The Fish Ladder: A Journey Upstream. London Bloomsbury, 2015.

Robinson, Tim. Connemara: Listening to the Wind. Dublin: Penguin Ireland, 2006.

Robinson, Tim. Connemara: The Last Pool of Darkness. Dublin: Penguin Ireland, 2008.

Robinson, Tim. Connemara: A Little Gaelic Kingdom. Dublin: Penguin Ireland, 2011.

Stempel-Lewis, John. Meadowland: The Private Life of an English Field. London: Black Swan, 2015.

Stempel-Lewis, John. The Running Hare. London: Black Swan, 2017.

Stout, Jeffery. "Naturalism." In Encyclopaedia of Religion, 2nd ed., edited by Lindsay Jones, Mircea Eliade and Charles J. Adams, 6429-30. Detroit: Macmillan Reference, 2005.

Tarlo, Harriet, ed. The Ground Aslant: An Anthology of Radical Landscape Poetry. Exeter: Shearsman, 2011.

Taylor, Charles. Sources of the Self. Cambridge: Cambridge University Press, 1989.

Taylor, Charles. Modern Social Imaginaries. Durham: Duke University Press, 2004.

Taylor, Charles. A Secular Age. Cambridge, MA: Belknap, 2007.

Vattimo, Gianni. Belief. Stanford: Stanford University Press, 1999. 
Vattimo, Gianni and Richard Rorty. The Future of Religion. New York: Colombia University, 2005.

Waugh, Evelyn. Scoop: A Novel About Journalists. London: Chapman and Hall, 1938.

Weber, Max. The Vocation Lectures. Translated by Rodney Livingstone. Indianapolis: Hackett, 2004.

White, Gilbert. Natural History of Selborne. Edited by Richard Maybe. London: Dent, 1993. Wilson, Stephen. The Magical Universe. London: Hambledon, 2000.

\section{Author biography}

Alexander J. B. Hampton is Assistant Professor in Christianity at the University of Toronto in the Department for the Study of Religion. His work in the philosophy of religion specialises in religious aesthetics and religion and nature. $\mathrm{He}$ is the author of Romanticism and the Re-Invention of Modern Religion (Cambridge University Press, forthcoming). A full list of publications is available at www. ajbhampton.com. 